\title{
Research on Logistics Capacity Evaluation and Improvement Countermeasures of Xi'an International Trade \& Logistics Park
}

\author{
Huizhen Wang ${ }^{1, *}$ \\ ${ }^{1}$ Xi'an International University, Shaanxi, Xi'an 710077, China \\ *Corresponding author. Email: 284405896@qq.com
}

\begin{abstract}
After more than 10 years of development, Xi'an International Trade \& Logistics Park has initially formed an industrial system dominated by international trade, trade logistics, port processing and manufacturing, e-commerce and new financial industries, which are supported by sports health, life supporting facilities, cultural creativity and bulk commodity trading. Meanwhile, it has built multimodal transport channel systems such as China- Europe Railway Express (Xi'an), cross-border e-commerce freight routes and sea-rail intermodal routes. It has become one of the separate areas of China (Shaanxi) Pilot Free Trade Zone. Firstly, this paper selects the evaluation index of logistics capacity for Xi'an international inland port by literature search and analysis, and then establishes an evaluation model to evaluate it. Secondly, some proposals are put forward according to the evaluation results. The Belt and Road trade logistics center and industrial cooperation demonstration center need to be set up to improve the logistics capacity of Xi'an International Inland Port. And a trade-oriented international logistics hub and international freight trains also help to improve the service level.

Keywords: Xi'an International Trade \& Logistics Park; logistics capacity evaluation; evaluation index;
\end{abstract}

Promotion Countermeasures

\section{SELECTION OF LOGISTICS CAPACITY EVALUATION INDEX OF XI'AN INTERNATIONAL TRADE \& LOGISTICS PARK}

Combined with relevant literature and the specific situation of Xi'an International Trade \& Logistics Park, five first-class indicators are selected: logistics supporting facilities, information and communication technology, international logistics operation environment and logistics talent reserve. Logistics supporting facilities include four secondary indicators: highway mileage, railway mileage, international routes and national asset investment in logistics industry. Considering the multimodal transport of international Land Port Logistics and air transportation, the secondary index of international route is selected. Considering that the international Land Port Logistics and road transportation are basically high-speed, the high-speed mileage is more in line with the actual situation; Information and communication technology selects two secondary indicators: the total amount of post and telecommunications services and Internet broadband users; The international logistics operation environment selects four secondary indicators: international freight trains, total import and export volume, total revenue of logistics related industries and freight volume; The logistics talent reserve selects two secondary indicators: the number of college graduates and the number of logistics employees. See Table 1 for details

Table 1. Evaluation index of logistics capacity of Xi'an International Trade \& Logistics Park

\begin{tabular}{l|l}
\hline Category & Indicator name \\
\hline \multirow{4}{*}{ Logistics supporting facilities } & Expressway mileage \\
\cline { 2 - 2 } & Railway mileage \\
\cline { 2 - 2 } & International routes \\
\cline { 2 - 2 } & Fixed asset investment in logistics industry \\
\hline \multirow{2}{*}{ Information and communication technology } & Total post and telecommunications business \\
\cline { 2 - 2 } & Internet broadband users \\
\hline International logistics operation environment & International freight train \\
\hline
\end{tabular}




\begin{tabular}{l|l}
\multirow{2}{*}{ Logistics talent reserve } & Total imports and exports \\
\cline { 2 - 2 } & Total revenue of logistics related industries \\
\cline { 2 - 2 } & The volume of freight transport \\
\hline & Number of college graduates \\
\cline { 2 - 2 } & Number of logistics employees \\
\hline
\end{tabular}

Table 2. Evaluation index data of logistics capacity of Xi'an International Trade \& Logistics Park

\begin{tabular}{|c|c|c|c|c|c|c|c|c|c|c|c|c|}
\hline Year & $\begin{array}{l}\text { Expressway } \\
\text { mileage } \\
(\mathrm{km})\end{array}$ & $\begin{array}{l}\text { Railway } \\
\text { mileage } \\
(\mathrm{km})\end{array}$ & $\begin{array}{l}\text { International } \\
\text { routes }\end{array}$ & $\begin{array}{c}\text { Fixed } \\
\text { investment } \\
\text { in logistics } \\
\text { industry } \\
\text { (100 million } \\
\text { yuan) }\end{array}$ & $\begin{array}{c}\text { Total post and } \\
\text { telecommunications } \\
\text { business }\end{array}$ & $\begin{array}{l}\text { Internet } \\
\text { broadband } \\
\text { users }\end{array}$ & $\begin{array}{l}\text { International } \\
\text { freight train }\end{array}$ & $\begin{array}{l}\text { Total } \\
\text { imports } \\
\text { and } \\
\text { exports }\end{array}$ & $\begin{array}{c}\text { Total } \\
\text { revenue of } \\
\text { logistics } \\
\text { related } \\
\text { industries } \\
\text { (100 million } \\
\text { yuan) } \\
\end{array}$ & $\begin{array}{l}\text { freight } \\
\text { volume } \\
\text { (10000 } \\
\text { tons) }\end{array}$ & $\begin{array}{c}\text { number } \\
\text { of college } \\
\text { graduates } \\
\text { in shaanxi } \\
\text { province } \\
(10000)\end{array}$ & $\begin{array}{c}\text { Number of } \\
\text { employees in } \\
\text { logistics } \\
\text { industry in } \\
\text { shaanxi } \\
\text { province } \\
(10000) \\
\end{array}$ \\
\hline 2014 & 4466 & 6929 & 49 & 2344 & 5666602 & 5524403 & 95 & 16807150 & 1969 & 135897 & 27.74 & 35.4 \\
\hline 2015 & 5094 & 7272 & 48 & 2682 & 7570868 & 6054228 & 135 & 18952493 & 2076.7 & 140908 & 29.97 & 35.7 \\
\hline 2016 & 5181 & 7512 & 46 & 2210 & 12038145 & 8029617 & 194 & 19763020 & 2215 & 149049 & 32.13 & 37.3 \\
\hline 2017 & 5279 & 8315 & 57 & 2672 & 9523115 & 9032156 & 1235 & 27196506 & 2444 & 163086 & 30.51 & 43.8 \\
\hline 2018 & 5475 & 8735 & 64 & 3048 & 23547914 & 10573968 & 2133 & 35128162 & 2583 & 173253 & 30.1 & 50.8 \\
\hline
\end{tabular}

Data source: Shaanxi statistical yearbook 2015-2019

Table 3. Weights of two main factors extracted

\section{LOGISTICS CAPABILITY EVALUATION OF XI'AN INTERNATIONAL TRADE \& LOGISTICS PARK}

\subsection{Determination of index weight}

Determining the number of factors that can explain the correlation between index variables is the first step of factor analysis. In this paper, the principal component analysis method is used for analysis, and the eigenvalue criterion is used to determine the number of factors. In order to facilitate the interpretation of the extracted factors, the variance maximization method is used for orthogonal rotation in the process of factor analysis. SPSS software is used to conduct factor analysis on the selected samples to obtain the factor eigenvalues and their contribution rates. In factor analysis, the contribution rate reflects the amount of information contained in each factor. In this paper, the principal component with eigenvalue greater than 1 is selected as the initial factor.

The contribution rate of the factor refers to the contribution degree of the factor to the whole, which is the ratio of its original data information. Therefore, it is very reasonable to use the contribution rate to explain the weight of the factor in the overall goal. Let the weight of fi be AI and its contribution rate be $\mathrm{Ai}, \quad(\mathrm{i}=1,2)$. Normalize the contribution rates of these two main factors according to formula (1):

$$
\mathrm{Fi}=\mathrm{ai} /(\mathrm{a} 1+\mathrm{a} 2)
$$

The contribution rates of these three factors are $82.158 \%$ and $12.811 \%$ respectively. After normalization, the weights of the two factors in the total goal are 0.8651 and 0.1349 respectively. See table 4 for details

\begin{tabular}{cc}
\hline Principal factor & weight \\
\hline $\mathrm{F}_{1}$ & 0.8651 \\
$\mathrm{~F}_{2}$ & 0.1349 \\
\hline
\end{tabular}

\subsection{Evaluation results of logistics capacity of Xi'an International Trade \& Logistics Park from 2014 to 2018}

Table 4. Evaluation results of logistics capacity of Xi'an international dry port from 2014 to 2018

\begin{tabular}{cc}
\hline Year & Comprehensive evaluation value \\
\hline 2014 & 1.40 \\
\hline 2015 & 2.38 \\
\hline 2016 & 1.65 \\
\hline 2017 & 2.07 \\
\hline 2018 & 2.67 \\
\hline
\end{tabular}

The data and weights in the previous part are used to evaluate the logistics capacity of Xi'an International Trade \& Logistics Park from 2014 to 2018. The evaluation results are as follows:

From the evaluation results, the overall logistics capacity of Xi'an International Trade \& Logistics Park showed an upward trend, only slightly decreased in 2016 compared with 2015. From the data, the decline in the evaluation results in 2016 was mainly due to the reduction of fixed investment in the logistics industry, which was improved in 2017. Therefore, there has been an upward trend in 2017 and 2018. 


\section{COUNTERMEASURES FOR IMPROVING LOGISTICS CAPACITY OF XI'AN INTERNATIONAL TRADE \& LOGISTICS PARK}

\subsection{Creating One Belt, One Road Business Logistics Center}

We should speed up one belt, one Road Agricultural Trade Center for international trade in Xi'an port, and expand and import agricultural and sideline products such as Kazakhstan, Uzbekistan and Russia. One belt, one road, one belt, one road, one belt, one road, is actively being put into the "one belt and one way" summit to further highlight the role of our province in integrating the "one belt and one road" development. Actively support Xi'an International Trade \& Logistics Park to undertake the transfer of export-oriented industries along the southeast coast and build Xi'an port into the largest scientific and technological processing and manufacturing base in the West. One belt, one road, is to build a ten commodity trading center and learn from the successful experience of Shanghai global commodity trading port in Xi'an. Vigorously develop the "Chang'an + cross-border e-commerce" model, support Xi'an International Trade \& Logistics Park to deepen cooperation with well-known e-commerce enterprises such as JD, Miya, Netease and Jiahelper, and introduce preferential policies to help the leading e-commerce and local e-commerce in Xi'an International Trade \& Logistics Park become bigger and stronger, so as to truly "buy, sell and enjoy the world".

\subsection{Creating One Belt, One Road Industrial Cooperation Demonstration Center}

Based on the introduction and cultivation of high-quality supply chain management enterprises, focus on the specific links such as the operation route, freight volume and cargo category of the "Chang'an" China Europe train, gather many industries and Xi'an International Trade \& Logistics Park, and build a multi-industry cooperation center with the "Chang'an" China Europe train as the core. Focus on supporting supply chain management enterprises, include them in the category of industries that encourage development, and give policy and financial support. Around the "one belt, one road" and "three trillion trillion" industries, we will provide quality and efficient supply chain management services along the "one belt and one road". We will link the government investment, enterprise investment, industrial integration, project sharing and strategic cooperation as a bridge to guide the trade and logistics industry to merge into the Changan Europe and China business. And through high-quality logistics enterprises to complete the aggregation of supply enterprises and high-quality supply sources, so as to build a more complete international logistics cargo transportation supply chain. Focusing on the competitiveness one of the "Changan one" central and European one, focusing on the one theme of "one belt, one road" industrial cooperation center, we build a west international logistics supply chain management platform integrating manufacturing, assembly, distribution, logistics, finance, freight forwarding and big data. It focuses on connecting the information platforms of government supervision, customs supervision, goods source enterprises and logistics enterprises, building a unified shared information platform, accelerating the cultivation of high-quality goods source enterprises and international logistics enterprises that can complete the general contracting of overall international logistics business in the market, improving the market service capacity of regulatory agencies, goods source enterprises and logistics enterprises, and implementing centralized storage and transportation, commodity inspection, customs declaration The international logistics business feature of "logistics + capital flow + information flow" integrating finance and insurance can provide personalized, customized and one-stop overall solutions for international logistics business according to market demand.

\section{BUILDING A TRADE-ORIENTED INTERNATIONAL LOGISTICS HUB}

In September 2019, the national development and Reform Commission and the Ministry of transport jointly issued the notice on doing a good job in the construction of national logistics hubs in 2019. A total of 23 logistics hubs were selected into the list of national logistics hubs in 2019 , and Xi'an Land Port national logistics hub was listed. Relying on Xi'an International Trade \& Logistics Park, based on the surrounding high-quality logistics facilities, guided by the spirit of the national development and Reform Commission, and taking the "Chang'an" China Europe train as the link and medium, promote the establishment of a trade-oriented international logistics hub and strengthen the connection and coordination with the surrounding high-quality logistics hubs, especially at the level of standardization and information platform sharing, We will promote the construction of an urban logistics hub and logistics business for China- Europe Railway Express connecting the east of Xi'an, gather many China- Europe Railway Express now running independently in Xi'an and transfer them to "Chang'an" for transit, form an international logistics network for China- Europe Railway Express, and build an efficient, electronic, information-based and scientific logistics network The supply chain logistics system of "Asia Europe channel + international Land Port Logistics hub + China Europe train freight network" promotes the "Chang'an" The competitiveness of China- Europe Railway Express , thus forming the basic support for a trade-oriented international logistics hub to take root in Xi'an, promoting the coordinated development of China- Europe Railway Express and international logistics business in the region 
east of Xi'an and the construction of a more standardized logistics market to central and Eastern Europe. Lay a solid foundation for a new land-based open highland.

\subsection{Suggestions on International Freight Train Operation}

First, optimize the network line. Establish a multimodal transport network system by integrating various modes of transportation such as highway, railway, sea and air. On the one hand, it opens up the international logistics channel through international railway intermodal transport to the West. Relying on the enterprise's sound logistics distribution network, advanced logistics information technology and successful platform operation mode, build the regional distribution network of Xi'an port and improve the service experience of "the last kilometer" of international and domestic transportation channels.

Secondly, improve customs clearance efficiency. Optimize the shipping process of China Europe train Chang'an, improve the container inbound weighing and deviation measuring equipment, reduce the turning in the station of Xi'an railway container center station, the arrival and landing of imported goods, ensure the seamless connection of all links of the process, shorten the time of goods in Xi'an railway container center station and improve the operation efficiency. Accelerate the construction of Xi'an port information system integrating comprehensive functions such as online space booking, business handling, document circulation, online fee settlement and information query, effectively connect the data of Xi'an Railway Container Central Station and Xi'an customs, optimize the train shipping process, and improve the informatization and intelligence level of train shipping. In terms of railway transportation, road transportation connection, informatization of upstream and downstream enterprises in the supply chain, intellectualization and mechanization of logistics business and electronation of tickets, there are informatization, intellectualization, sharing and co construction in the "Chang'an" China Europe train, breakthrough and innovation, look for a new international logistics business model, and try a new return journey One belt, one road, is to build a hub city with international logistics nodes as the goal. With the wider "one belt and one way" logistics as the vision, the transport efficiency and heavy haul rate and the aggregation ability of the return freight source will be improved.

Finally, strengthen regional cooperation. Strengthen the cooperation with Chongqing, Chengdu, Hefei, Yiwu, Suzhou, Zhengzhou and other places in the operation of Sino European freight trains, strengthen the cooperation and interaction in policy guidance, financial subsidies, talent exchange, business integration and other aspects in these regions, and jointly build and share relevant information, infrastructure conditions, goods source enterprises, information platforms Favorable policies, etc. In combination with the trend of international logistics hub construction, vigorously promote regional resources such as international multimodal transportation, finance and insurance, supply chain business and financial subsidies, and carry out innovative cooperation with many regions east of Xi'an at all levels, so as to further effectively promote the customs declaration, freight transportation, commodity inspection Cooperation and dialogue between financial and other departments, strive to achieve the sharing of relevant information under the authority constraints of electronic bills and regulatory information platform, and improve the efficiency of customs clearance of single ticket goods, so as to improve the efficient connection between China EU trains and central and Eastern Europe.

\section{CONCLUSION}

Firstly, this paper selects the evaluation indicators of Xi'an International Trade \& Logistics Park logistics capacity through literature search and analysis, and then establishes an evaluation model to evaluate the logistics capacity of Xi'an International Trade \& Logistics Park. From the evaluation results, the logistics capacity of Xi'an International Trade \& Logistics Park shows an upward trend as a whole, and only slightly decreased in 2016 compared with 2015. From the data, the decline in the evaluation results in 2016 was mainly due to the decrease in fixed investment in the logistics industry, which was improved in 2017. Therefore, there has been an upward trend in 2017 and 2018. One belt, one road, one belt, one road, one is the center of Xi'an's international port and port logistics. The other is the "one belt and one road" Industrial Cooperation Demonstration Center.

\section{ACKNOWLEDGMENT}

Logistics Education Instruction Committee of the Ministry of education and the project of China Logistics Society (JZW2021006);

Xi'an Social Science Fund Project (JG59);

Shaanxi Federation of Social Sciences project (2021ND0319);

Shaanxi Social Science Foundation Project (2020D042);

Shaanxi international cooperation base one belt, one road, international land port logistics joint research center project (XAIUGH202004).

\section{REFERENCES}

[1] Soni U., Jain V., Kumar S. Measuring Supply Chain Resilience Using A Deterministic Modeling Approach[J]. Computers \& Industrial Engineering,2014.

[2] Walter C.K., Poist R.F. Desired Attributes of an Land Port: Shipper vs. Carrier Perspectives

[J].Transportation Journal, 2003, 42(5): 42- 55. 
[3] Wiegmans B, Witte P A, Spit T J M. Inland port performance: a statistical analysis of Dutch inland ports[J].Transportation Research Procedia,2015,(8).

[4] Yan Fei. Research on Coordination Mechanism of logistics service supply chain [D]. Doctoral dissertation of Chang'an University, 2009. (In Chinese)

[5] Ding Jianghua. Study on site selection and planning of Xi'an international port area [D]. Xi'an: Xi'an
University of architecture and technology, 2008. (In Chinese)

[6] Planning and design of logistics service supply chain capability integration of Xu Dehong and Xiping international Land Port s-Taking Xi'an International Trade \& Logistics Park as an example [J]. Continental Bridge vision, 2012.12: 60-63. (In Chinese) 